\title{
Konstruksi Plasmid Rekombinan untuk Inisiasi Translasi Enhance Green Fluorescent Protein oleh Internal Ribosomal Entry Site HIV-1
}

\author{
Construction of Recombinant Plasmid for Translation Initiation of Enhanced Green Fluorescent \\ Protein by HIV-1 Internal Ribosomal Entry Site
}

\author{
Cintera Rahmagiarti' ${ }^{1}$, Silvia Tri Widyaningtyas ${ }^{2}$, dan Budiman Bela ${ }^{2,3^{*}}$ \\ 'Program Magister Ilmu Biomedik, Fakultas Kedokteran, Universitas Indonesia, \\ Jl. Salemba No.6 Jakarta Pusat 10430, Indonesia \\ ${ }^{2}$ Pusat Riset Virologi dan Kanker Patobiologi Fakultas Kedokteran Universitas Indonesia \\ Rumah Sakit Umum Pusat Cipto Mangunkusumo, Jl. Salemba No.6 Jakarta Pusat 10430, Indonesia \\ ${ }^{3}$ Departemen Mikrobiologi, Fakultas Kedokteran, Universitas Indonesia, \\ Jl. Pegangsaan Timur No.16 Jakarta Pusat 10320, Indonesia \\ *Korespondensi Penulis : budiman.bela@ui.ac.id ; budiman.bela@gmail.com
}

Submitted: 28-02-2018, Revised:30-07-2018, Accepted: 30-07-2018

DOI: http://dx.doi.org/10.22435/mpk.v28i2.181

\begin{abstract}
Abstrak
Human Immunodeficiency Virus (HIV) merupakan virus penyebab Acquired Immunodeficiency Virus Syndrome (AIDS). Genom HIV memiliki struktur cap di 5' dan poliadenilasi di 3' mRNA sehingga proses inisiasi translasi melalui pemindaian 5'cap pada struktur untranslated region (UTR) di 5' mRNA HIV. Protein Vpr yang dihasilkan selama replikasi virus menyebabkan pemindaian melalui 5'cap terhambat sehingga HIV-1 dapat langsung merekrut ribosom pada kodon awal translasi melalui struktur internal ribosomal entry site (IRES). Aktivitas IRES tinggi pada fase G2/M dan ekspresi gen tinggi pada sel line monosit (THP1) dan limfosit (HPB-ALL). Namun, peran IRES HIV-1 belum diketahui pada sel tidak membelah yang merupakan sel target pada infeksi HIV-1. Penelitian ini bertujuan membuat plasmid rekombinan pengkode enhanced green fluorescent protein (EGFP) sebagai reporter dalam inisiasi translasi oleh IRES HIV-1. Sekuens nukleotida EGFP yang terkandung dalam DNA sisipan ditempatkan di hilir sekuens IRES HIV1 didapatkan dari amplifikasi PCR menggunakan pcDNA5FRT/TO IRES-EGFP sebagai DNA cetakan. Sekuens sisipan IRES HIV-1_egfp dan pcDNA3.1(+) dipotong dengan EcoRI dan Apal, lalu diligasi dengan DNA ligase dan campuran ligasi digunakan untuk transformasi ke sel Escherichia coli (E.coli) Top 10 kompeten. Verifikasi koloni transforman dilakukan dengan PCR, restriksi endonuklease, dan sekuensing. E.coli yang ditransformasi dengan campuran DNA ligasi menghasilkan $70 \mathrm{koloni}$, sementara kontrol ligasi berupa vektor terpotong tanpa DNA sisipan menghasilkan 5 koloni, dan kontrol sel E.coli kompeten tidak menunjukkan pertumbuhan pada agar Ampicillin. 19 dari 20 koloni transforman yang diverifikasi dengan PCR menunjukkan adanya DNA sisipan. Analisis restriksi endonuklease dari DNA rekombinan memverifikasi ukuran DNA sisipan dan DNA vektor masing-masing 1067 pb dan 5379 pb. Verifikasi dengan sekuensing DNA teridentifikasi tidak terdapat mutasi. Berdasarkan hasil uji, dapat disimpulkan proses subkloning DNA sisipan IRES HIV-1_egfp ke dalam pcDNA3.1(+) berhasil dilakukan.
\end{abstract}

Kata kunci: Kloning, IRES, egfp, HIV-1.

\begin{abstract}
Human Immunodeficiency Virus (HIV) is a virus that causes Acquired Immunodeficiency Virus Syndrome (AIDS). The HIV genome has a cap structure at 5' and polyadenylation at 3' on mRNA resulting in a translation initiation through scanning at 5'untranslated region (UTR). The Vpr protein produced during viral replication causes the 5'cap scanning to be inhibited so HIV-1 can directly recruit the ribosome at the start codon via internal ribosomal entry site (IRES). The IRES activity is high at G2/M phase and highest
\end{abstract}


expression in monocyte cell line (THP-1) and lymphocyte (HPB-ALL). The role of HIV IRES however, is not yet known in infection of nondividing cells by HIV-1. This study aims to construct recombinant plasmid for translation initiation of enhanced green fluorescent reporter protein (EGFP) by HIV-1 IRES. Insert DNA containing nucleotide sequence of EGFP that was placed downstream to HIV-1 IRES, was obtained by PCR amplification using pcDNA5FRT/TO IRES-EGFP as template DNA. The insert DNA HIV-1 IRES_egfp and pcDNA3.1(+) were digested with EcoRI and Apal, ligated with DNA ligase and the ligation mixture was used for transformation of competent Top 10 Escherichia coli (E. coli). Verification of transformant colonies was performed with PCR, endonuclease restriction, and sequencing. Transformation of E. coli with DNA ligation mixture produced 70 colonies, while control ligation of restricted vector without insert DNA produced 5 colonies, and control competent cells of E. coli showed no growth on Ampicillin agar plates. 19 of 20 transformant colonies that were screened by PCR showed the presence of insert DNA. Endoculease restriction analysis of the recombinant DNA verified the sizes of insert and vector DNA of respectively $1067 \mathrm{bp}$ and $5379 \mathrm{bp}$. Verification by DNA sequencing did not identify any mutation. Based on the test results, it can be concluded that the subcloning process of IRES HIV-1_egfp DNA insert into pcDNA3.1(+) was successfully performed.

Keywords : Cloning, IRES, egfp, HIV-1

\section{PENDAHULUAN}

Human Immunodeficiensy Virus (HIV) tipe 1 merupakan virus dari famili Retroviridae dengan genus Lentivirus. HIV-1 merupakan agen penyebab Acquired Immunodeficiency Virus Syndrome (AIDS). HIV-1 memiliki 2 kopi genom RNA untai tunggal positif $(\sim 9 \mathrm{~kb})$ serta menggunakan perangkat seluler untuk mengekspresikan protein struktural (Gag dan Env), enzim (reverse transkriptase), dan protein asesoris (Tat, Nef, Vpu.Vpx, Vif, Rev, dan Vpr). ${ }^{1,2}$ Proses transkripsi HIV-1 diproduksi dalam nukelus lalu mRNA dimodifikasi dengan penambahan cap atau 7-metilguanosin $(\mathrm{m} 7 \mathrm{G})$ di 5' dan poliadenilasi di 3' mRNA. Struktur tersebut dapat menginisiasi translasi melalui mekanisme 5'cap (cap-dependen). ${ }^{3}$

Mekanisme inisiasi translasi melalui capdependen diawali dengan perekrutan kompleks protein faktor inisiasi eukariotik 4F (eIF4F) yang tersusun dari sub unit pengikatan 5'cap (eIF4E), RNA helikase (eIF4A), dan protein scaffolding (eIF4G) ke 5'cap virus. Kompleks eIF4F berikatan dengan eIF4B dan /atau eIF4H untuk membuka struktur sekunder lokal dan merekrut kompleks pra-inisiasi 43S (ribosom 40S, eIF3, eIF1, dan eIF1A) ke hulu open reading frame (ORF). Kodon awal (AUG) diidentifikasi melalui pemindaian dari 5' ke 3' mRNA oleh 43S hingga AUG tercapai. tRNA berpasangan dengan kodon AUG, ribosom 60S bergabung lalu protein inisiasi faktor terlepas sehingga proses translasi berjalan. ${ }^{2}$ Namun, selama infeksi HIV-1, protein Vpr menginduksi sel dalam fase G2/M serta hipofosforilasi eIF4E dan 4e-BP sehingga mekanisme inisiasi melalui cap-dependen dihambat 50-60\%. ${ }^{4}$ Oleh karena itu, HIV-1 memiliki mekanisme inisiasi translasi alternatif yaitu internal ribosome entry site (IRES).., 5

Posisi IRES HIV-1 diketahui terletak pada 5'UTR. ${ }^{6}$ Brasey et al melaporkan bahwa aktivitas IRES minimal terdapat pada basa ke 104-336 dari awal 5'UTR dengan 4 domain penting yaitu primer binding site (PBS), dimerization site (DIS), splice donor site (SD), dan packaging signal $(\Psi){ }^{3}$ Aktivitas IRES 5'UTR HIV-1d dilaporkan tinggi dalam mengekspresikan gen pada sel tropisme dari HIV-1 yaitu sel line THP-1 (monosit) dan sel line HPB-ALL (limfosit). ${ }^{7}$ Aktivitas IRES HIV-1 juga diuji pada sel Hela yang diberi perlakuan agar konstan di beberapa fase sel dan menghasilkan aktivitas tertinggi pada fase G2/M.,8 Namun, belum diketahui bagaimana peran IRES HIV1 pada sel tidak membelah manusia seperti sel makrofag turunan monosit. Sel makrofag merupakan salah satu target sel dalam infeksi awal HIV-1. Oleh karena itu, pada penelitian ini dibuat konstruksi DNA pengekspresi protein reporter fluoresen (eGFP) dibawah kontrol promoter mamalia (CMV) dan IRES HIV.

Tujuan penelitian ini adalah untuk membuat konstruksi plasmid rekombinan guna mempelajari peran IRES HIV-1 pada sel tidak membelah seperti makrofag turunan monosit. Apabila IRES HIV-1 memiliki peran dalam sel tidak membelah maka kondisi sel terinfeksi HIV1 dalam sel makrofag pada penelitian mendatang diharapkan dapat dihambat oleh faktor-faktor 
terkait aktivitas IRES HIV-1 apabila IRES HIV-1 memiliki peran dalam infeksi di sel tersebut.

\section{METODE}

Penelitian dilakukan di laboratorium Pusat Riset Virologi dan Kanker Patologi (PRVKP) RSCM-FKUI. Semua bahan yang digunakan dalam penelitian berasal dari laboratorium PRVKP-FKUI. Plasmid cetakan yang digunakan dalam penelitian ini adalah pcDNA5FR/TO yang sudah tersisipi DNA IRES HIV-1 dan egfp. Plasmid untuk subkloning menggunakan pcDNA3.1(+) dengan promoter CMV.

Bakteri yang digunakan untuk propagasi plasmid adalah E.coli strain Top10. Ezim untuk pengklonan adalah EcoRI dan ApaI [New England Biolabs]

Sekuens IRES HIV-1 dan egfp sebagai DNA sisipan didapatkan dengan mengamplifikasi sekuen IRES HIV-1_egfp dalam pcDNA5FRT/ TO (125 ng) menggunakan primer universal CMV forward dan BHG reverse $\left[1^{\text {st }}\right.$ base] pada mesin thermal cycler [Applied Biosystem]. Campuran reaksi untul total volume 50 $\mu$ l: Platinum Pfx DNA Polimerase (1U) [Thermo scientific], masingmasing $0,3 \mu \mathrm{M}$ CMV forward dan BHG reverse $\left[1^{\text {st }}\right.$ base], 1x larutan dapar \& PCR enhancer, 0,3 mM dNTP [Invitrogen], $1 \mathrm{mM} \mathrm{MgSO} 4$ ditambahkan dengan nuclease free water sampai volum $50 \mu \mathrm{L} .{ }^{9}$ Kondisi PCR: 1x siklus $94^{\circ} \mathrm{C} 2$ menit; 35x siklus $94^{\circ} \mathrm{C} 15$ detik, $55^{\circ} \mathrm{C} 30$ detik, $68^{\circ} \mathrm{C} 1$ menit; $1 \mathrm{x}$ silus $68^{\circ} \mathrm{C} 10$ menit.

Kedua ujung amplikon dan vektor pcDNA3.1(+) dipotong dengan EcoRI dan ApaI lalu dipurifikasi dengan low melting agarose (LMA) 1,2\% (b/v) dalam TAE 1x, dan desalting [Qiagen]. Visualisasi potongan DNA dilakukan pada elektroforesis agarose $0,8 \%(\mathrm{~b} / \mathrm{v}) 100 \mathrm{~V} 30$ menit. DNA sisipan dan vektor murni dengan ukuran sesuai lalu diligasi dengan T4 DNA ligase [Invitrogen] dengan perbandingan DNA sisipan dan vektor $3: 1$ pada $16^{\circ} \mathrm{C}$ selama 16 jam.

E.coli strain Top10 ditumbuhkan dalam $5 \mathrm{ml}$ luria bertani (LB) cair lalu dibuat kompeten dengan $100 \mathrm{mM} \mathrm{MgCl} 2$ dan $\mathrm{CaCl} 2$ dingin. DNA yang akan dimasukkan dalam E.coli: Tabung 1 (DNA ligasi: 25 ng vektor $+14,9$ ng DNA sisipan), tabung 2 (kontrol ligase: 25 ng vektor), tabung 3 (pcDNA3.1(+) wild type $50 \mathrm{ng}$ ), dan tabung 4 E.coli tanpa DNA sebagai kontrol negatif.
Transformasi E.coli dengan heat shock pada suhu $38^{\circ} \mathrm{C}$ selama 90 detik lalu $4^{\circ} \mathrm{C}$ selama 60 detik. E.coli ditumbuhkan dalam LB agar (+ ampicillin 1: 1000 medium) selama 16 jam pada suhu $37^{\circ} \mathrm{C}$.

Klona yang tumbuh pada LB agar diverifikasi keberadaan DNA rekombinan melalui tiga tahapan. Verifikasi pertama menggunakan PCR koloni dengan total volum $50 \mu \mathrm{L}$ dengan komposisi reaksi: Dream Taq DNA polimerase $(1,25 \mathrm{U})$ [Thermoscientific], masing-masing 0,2 $\mu \mathrm{M}$ primer $\mathrm{CMV}$ forward dan $\mathrm{BGH}$ reverse $\left[1^{\text {st }}\right.$ base, USA], dNTP mix (0,2 mM), 1x larutan dapar (1/10 volume reaksi), dan $2 \mathrm{mM} \mathrm{MgCl} 2 .{ }^{10}$ Kondisi reaksi PCR : $1 \mathrm{x}$ siklus $95^{\circ} \mathrm{C} 3$ menit; 35x siklus $95^{\circ} \mathrm{C} 30$ detik, $55^{\circ} \mathrm{C} 30$ detik, $72^{\circ} \mathrm{C} 2$ menit; $1 \mathrm{x}$ siklus $72^{\circ} \mathrm{C} 10$ menit. Visualisasi DNA amplikon hasil PCR koloni dengan elektroforesis agaroses $0,8 \% \quad(\mathrm{~b} / \mathrm{v}) \quad 100 \mathrm{~V} 30$ menit. Lalu dilanjutkan dengan verifikasi berikutnya yaitu pemotongan DNA rekombinan dengan enzim EcoRI dan ApaI, serta sekuensing.

\section{HASIL}

Hasil PCR dan verifikasi restriksi DNA sisipan diperlihatkan pada Gambar 1.

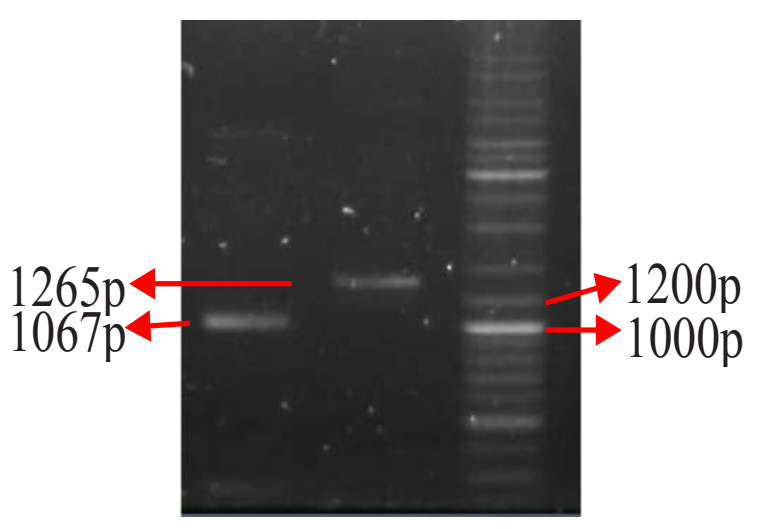

Gambar 1. Visualisasi DNA Sisipan IRES HIV1_egfp setelah Diverifikasi dengan Restriksi. Lajur M (Marka); 1 (DNA Amplikon dipotong EcoRI \& ApaI); 2 (Amplikon).

Amplikon yang dihasilkan oleh DNA sisipan yang mengandung sekuens IRES HIV-1 dan egfp, berukuran $1265 \mathrm{pb}$. Amplikon lalu dipotong dengan EcoRI di 5' dan ApaI di 3' menghasilkan DNA berukuran $1067 \mathrm{pb}$.

Plasmid vektor pcDNA3.1(+) wild type berukuran $5428 \mathrm{pb}$. Hasil restriksi vektor plasmid pcDNA3.1(+) dengan EcoRI dan 
ApaI menghilangkan $49 \mathrm{pb}$ (tidak terlihat pada visualisasi agarose $0,8 \%$ ) sehingga plasmid vektor yang siap diligasikan dengan DNA sisipan berada pada ukuran marka 5000-6000 pb (5379 pb) (Gambar 2).

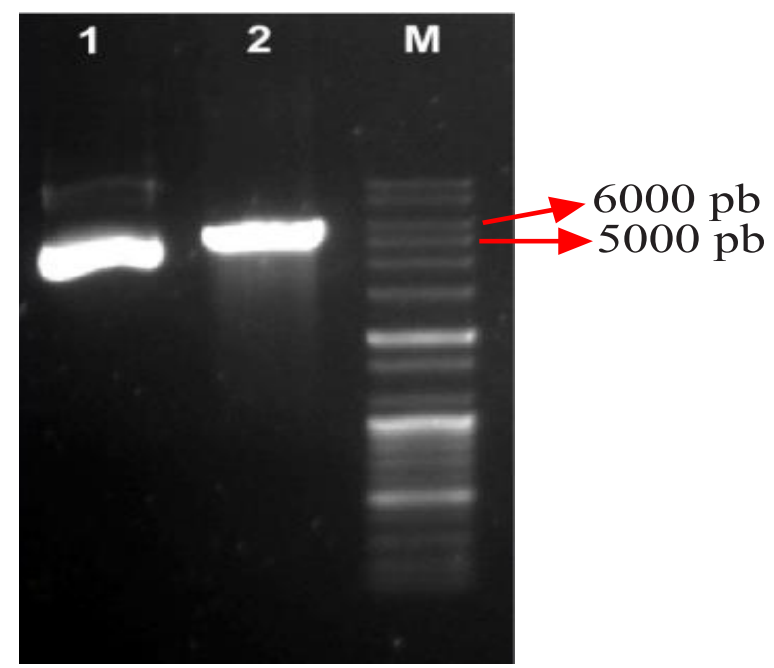

Gambar 2. Hasil pcDNA3.1 dengan EcoRI dan ApaI. Lajur M (Marka); 1 (pcDNA3.1 Tidak Direstriksi); 2 (pcDNA3.1 Direstriksi dengan EcoRI dan ApaI).

Vektor plasmid (pcDNA3.1) dan DNA sisipan yang telah dipotong dengan ApaI dan EcoRI diligasikan lalu menghasilkan DNA rekombinan pcDNA3.1_IRES HIV-1_egfp. Proses ligasi berhasil atau tidak dilihat dari hasil transformasi pada E.coli di LB agar (+ ampicillin). Hasil transformasi E.coli dengan DNA tertera pada Tabel 1.

Tabel 1. Hasil Transformasi E.coli

\begin{tabular}{clc}
\hline Tabung & DNA yang Ditransformasikan ke E.coli & $\begin{array}{c}\text { Jumlah } \\
\text { Koloni }\end{array}$ \\
\hline 1 & $\begin{array}{l}\text { DNA hasil ligasi (pcDNA3.1_IRES } \\
\text { HIV-1_egfp) }\end{array}$ & \pm 70 \\
2 & $\begin{array}{l}\text { Kontrol ligasi (pcDNA3.1(+) yang dipo- } \\
\text { tong ApaI_EcoRI) }\end{array}$ & \pm 5 \\
3 & $\begin{array}{l}\text { Kontrol sel kompeten (pcDNA3.1(+) } \\
\text { wild type) }\end{array}$ & \pm 100 \\
4 & Kontrol negatif(Tanpa DNA) & 0 \\
\hline
\end{tabular}

Koloni E.coli yang tumbuh pada LB agar (+ Ampicillin) setelah ditransformasi oleh DNA ligasi, lalu dipilih secara acak untuk dilakukan verifikasi dengan PCR koloni. Sebanyak 20 koloni replika yang di-running PCR, 19 koloni memiliki amplikon berukuran $1265 \mathrm{pb}$ dan hanya 1 koloni yang tidak terdapat DNA sisipan (Gambar 3).

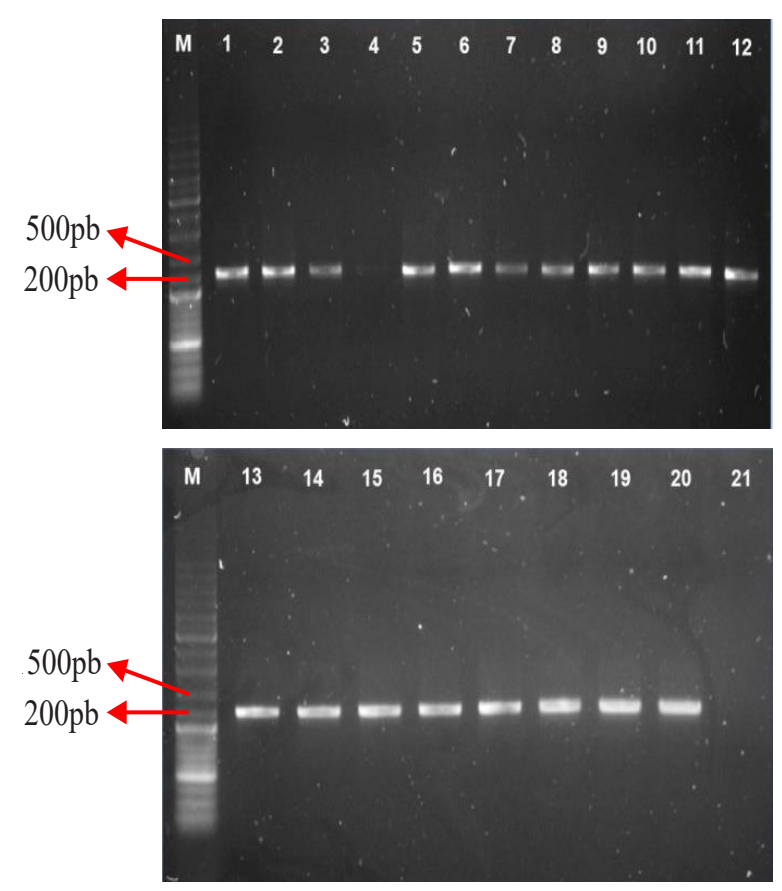

Gambar 3. Hasil PCR koloni pcDNA3.1_IRES HIV-1 egfp. Lajur M (Marka); Lajur 1-20 (koloni transforman campuran ligasi); 21 (kontrol negatif PCR).

Koloni nomor 19 dipilih secara acak untuk dilanjutkan ke tahapan verifikasi selanjutnya yaitu restriksi dengan EcoRI dan ApaI. Hasil verifikasi menunjukkan bahwa terdapat 2 pita DNA, dengan pita pertama berada di kisaran 5000-6000 pb (5379 pb) menunjukkan vektor plasmid dan pita kedua berada di kisaran 1000-2000 pb (1067 pb) menunjukkan DNA sisipan yang sudah terpisah dari vektor plasmid (Gambar 4).

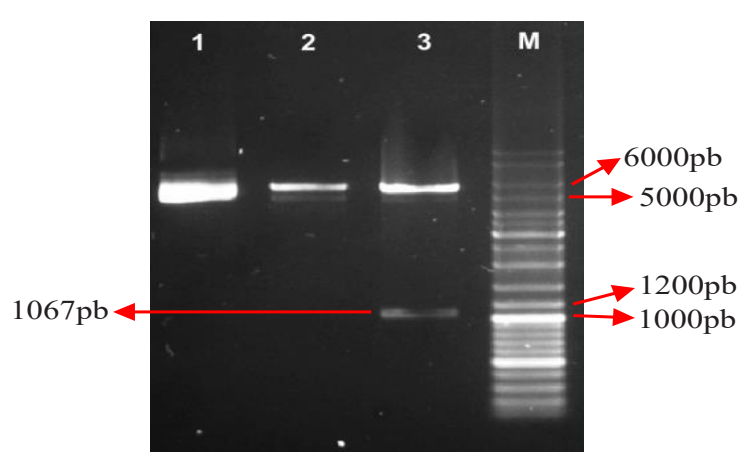

Gambar 4. Hasil Verifikasi DNA Rekombinan dengan EcoRI \& ApaI. Lajur M (Marka); 1 (pcDNA3.1 wild type); 2 (pcDNA3.1 wild type dipotong EcoRI \& ApaI; 3(pcDNA3.1 IRES HIV-1_egfp dipotong EcoRI \& ApaI). 
Koloni 19 berhasil terverifikasi pada dua lini pertama tahapan verifikasi. Lalu DNA plasmid koloni 19 diisolasi dan dilakukan sekuensing untuk mengetahui susunan basa dan ketepatan orientasi DNA sisipan dalam plasmid vektor. Hasil sekuensing menunjukkan tidak terdapat perubahan basa dibandingkan dengan sekuens referensi (pcDNA5FRT/TO_IRES HIV-1_egfp) serta orientasi DNA sisipan sesuai dan tidak terdapat perubahan kerangka baca pada gen egfp (hasil sekuensing tidak dilampirkan karena dalam proses hak paten).

\section{PEMBAHASAN}

Plasmid pcDNA3.1(+) digunakan dalam penelitian karena sistem ekspresi diperantarai oleh promoter CMV yang memiliki beberapa kelebihan yaitu dapat meregulasi ekspresi gen secara luas pada beberapa tipe sel mamalia, memiliki kekuatan dalam mengekspresikan gen tertinggi dibandingkan dengan promoter lain yang biasa digunakan dalam sistem ekspresi mamalia, seperti SV40, RSV, dan promoter mamalia. Plasmid pcDNA3.1(+) juga mengandung gen penyebab resisten ampicillin untuk seleksi klona transforman dengan antibiotik ampicillin serta memiliki daerah origin SV40 sehingga plasmid dapat direplikasi secara episomal (replikasi di luar kromosom inti) dalam sel yang terinfeksi laten oleh SV40 atau sel yang mengekspresikan large T-antigen SV40. ${ }^{11}$

Proses untuk mendapatkan DNA sisipan yang mengandung sekuens IRES HIV-1 dan egfp diperoleh dengan teknik PCR menggunakan enzim Platinum $P f x$ DNA polimerase karena memiliki aktivitas eksonuklease dari 3' ke 5' atau proofreading. Hal tersebut meminimalisasi terjadinya kesalahan pasangan basa oleh DNA polimerase dalam pengklonaan. ${ }^{12}$

Plasmid dan DNA sisipan dipotong dengan enzim endonuklease ApaI dan EcoRI. Kedua enzim tersebut memiliki aktivitas hanya memotong di satu situs pada plasmid dan menghasilkan potongan berujung lancip atau sticky end (ApaI = 5'-GGGCC/C-3'; EcoRI = 5'-G/AATTC-3'). Teknik pengklonaan dengan enzim yang menghasilkan potongan sticky end lebih efisien dalam proses ligasi. Hal tersebut dikarenakan ujung lancip bebas dapat saling berpasangan dengan komplemen ujung lancip lain melalui ikatan hidrogen sehingga membentuk ikatan yang relatif stabil. ${ }^{13}$

DNA sisipan dan vektor setelah dipotong kedua enzim lalu dimurnikan pada elektroforesis low melting agarose (LMA). LMA memiliki prinsip memisahkan DNA berdasarkan kecepatan migrasi dalam arus listrik yang dipengaruhi oleh ukuran DNA dimana DNA berukuran kecil akan bermigrasi lebih cepat dibandingkan DNA berukuran lebih besar. ${ }^{14}$ Oleh karena itu, DNA spesifik akan terpisah dengan DNA non-spesifik dan akan tervisualisasi selama proses LMA.

Setelah DNA terpisah pada LMA, DNA dimurnikan dengan metode desalting [Qiagen]. Prinsip dari desalting adalah adsorpsi DNA pada partikel silika dari QIAEX II [Qiagen] dalam kondisi lingkungan dengan konsentrasi garam tinggi dari pereaksi QXI [Qiagen]. Konsentrasi garam tinggi akan merusak ikatan hidrogen antar gula dalam polimer agarose, mendisosiasi ikatan antara DNA dan protein, serta memodifikasi struktur air sehingga menekan DNA untuk dapat teradsorpsi pada partikel silika. Pengotor akan berada di supernatan setelah proses sentrifugasi. Kontaminasi garam-garam pada pelet DNA akan dihilangkan pada tahapan pencucian dengan etanol absolut. Setelah itu, DNA dilarutkan dengan larutan elusi yaitu 1/3 TE (10 mM Tris-Cl, $1 \mathrm{mM}$ EDTA, pH 8) lalu DNA vektor dan DNA sisipan yang telah murni siap untuk diligasi. ${ }^{15}$

Ligasi dilakukan untuk menggabungkan ikatan fosfodiester antara DNA sisipan IRES HIV-1_egfp dengan vektor pcDNA3.1(+). DNA hasil ligasi ditransformasi ke E.coli kompeten menggunakan larutan $\mathrm{MgCl}_{2}$ dan $\mathrm{CaCl}_{2}$ dingin disertai dengan suhu tinggi atau heat shock untuk melihat keberhasilan proses ligasi. Konsentrasi garam tinggi disertai dengan pemanasan akan membuat permeabilitas membran sel E.coli terganggu sehingga DNA naked di sekitar bakteri dapat masuk ke dalam sitoplasma. ${ }^{13,16}$

E.coli tumbuh dari koloni yang ditransformasi oleh DNA ligasi 12 kali lebih banyak dibandingkan kontrol ligasi (E.coli ditransformasi dengan vektor yang sudah dipotong $A p a \mathrm{I}$ dan EcoRI). Hal tersebut mengindikasikan adanya keberhasilan proses transformasi dan ligasi. Koloni dari kontrol ligasi dapat tumbuh kemungkinan karena terdapat plasmid vektor yang belum terpotong. Sedangkan kontrol negatif E.coli strain Top 10 yang tidak diberikan DNA rekombinan menunjukkan bahwa proses kompeten berhasil karena tidak ada kontaminasi dari bakteri rekombinan lain.

Dengan demikian, konstruksi pcDNA3.1_ IRES HIV-1_egfp telah terverifikasi dengan baik berdasarkan kesesuaian ukuran amplikon DNA sisipan (IRES HIV-1_egfp) dan vektor pcDNA3.1(+) dengan ukuran pita DNA sisipan 
dan vektor setelah dipotong dengan enzim EcoRI dan ApaI, serta sekuensing. DNA rekombinan yang telah dikonstruksi dikemudian hari dapat digunakan untuk memelajari peran IRES HIV-1 pada sel tidak membelah, seperti makrofag turunan monosit berdasarkan ekspresi gen reporter egfp yang berada dalam konstruk DNA rekombinan.

\section{KESIMPULAN}

Proses pengklonaan IRES HIV-1_egf $p$ ke dalam plasmid pcDNA3.1(+) berhasil dilakukan dan telah terverifikasi dengan baik, terbukti tidak mengandung mutasi serta DNA sisipan terklona dalam orientasi yang benar pada vektor pcDNA3.1_IRES HIV-1_egfp.

\section{SARAN}

Konsentrasi DNA (ng) (pcdna3.1 wild type) sebagai kontrol positif transformasi ke E.coli Top 10 pada penelitian ini berbeda dengan DNA rekombinan pada campuran ligasi. Untuk proses transformasi sebaiknya digunakan DNA vektor plasmid dengan konsentrasi yang sama pada kontrol vektor tanpa DNA sisipan maupun pada ligasi campuran DNA vektor dan DNA sisipan. Hal ini diperlukan untuk memperkirakan dengan lebih akurat kemungkinan mendapatkan DNA rekombinan mengandung DNA sisipan pada koloni transforman yang diperoleh pada pelat agar ampisilin.

\section{UCAPAN TERIMA KASIH}

Ucapan terima kasih ditujukan kepada dr. Fera Ibrahim, M.Sc,.PhD,Sp.MK(K) selaku pimpinan instritusi Pusat Riset Virologi dan Kanker Patologi (PRVKP) FKUI-RSCM, Dr. dr. Budiman Bela, Sp.MK(K) dan Dr. drh. Silvia Tri Widyaningtyas, M.Biomed yang telah membimbing dalam penelitian ini, Ekawati Betty, S.Si, M.Biomed, serta kepada pembiayaan penelitian ini yang diperoleh melalui program Insentif Riset Sistem Inovasi Nasional (SINas) tahun 2016 dari Kementerian Riset Teknologi dan Pendidikan Tinggi. Seluruh penelitian dilakukan di laboratorium Pusat Riset Virologi dan Kanker Patologi FKUI-RSCM.

\section{DAFTAR PUSTAKA}

1. Flint J, Racaniello VR, Rall GF, Skalka AM, Enquist LW. Principles of virology. Vol 1. 4th ed. Washington: ASM Press; 2015.

2. Breyne S De, Soto-rifo R, López-lastra M, Ohlmann T. Translation initiation is driven by different mechanisms on the HIV-1 and HIV2 genomic RNAs. Virus Res. 2013;171:366381.

3. Brasey A, Lopez-Lastra M, Ohlmann T, et al. The leader of human immunodeficiency virus type 1 genomic RNA harbors an internal ribosome entry segment that is active during the $\mathrm{G} 2 / \mathrm{M}$ phase of the cell cycle. J Virol. 2003;77(7):3939-3949.

4. Pyronnet S, Dostie J, Sonenberg N. Suppression of cap-dependent translation in mitosis. Genes Dev. 2001:2083-2093.

5. Araujo PR, Yoon K, Ko D, et al. Before it gets started : regulating translation at the 5 UTR. Comp Funct Genomics. 2012:1-8.

6. Ohlmann T, Mengardi C, Lopez-Lastra M. Translation initiation of the HIV-1 mRNA. Translation. 2014;2(2):1-12.

7. Plank TM, Whitehurst JT, Kieft JS. Cell type specificity and structural determinants of IRES activity from the 5' leaders of different HIV-1 transcripts. Nucleic Acids Res. 2013;41(13):6698-6714.

8. Vallejos M, Deforges J, Plank TM, et al. Activity of the human immunodeficiency virus type 1 cell cycle-dependent internal ribosomal entry site is modulated by IRES trans -acting factors. Nucleic Acids Res. 2011;39(14):61866200.

9. Invitrogen.Platinum TMPfx DNAPolymerase. Carlsbad: Thermo Fisher Scientific Inc; 2016.

10. Information P. Thermo Scientific DreamTaq PCR Master Mix (2X).

11. I n vit r o g e n . p c D N A T M $3.1(+)$ pcDNATM3.1(-). Vol 1. Carlsbad: Invitrogen Corporation; 2010.

12. Invitrogen Corporation. High fidelity and high specificity - AccuPrime TM Pfx DNA Polymerase gives you both. Invit life Technol. 2002:8-9.

13. Brown T. Gene cloning \& DNA analysis an introduction. 6th ed. (Brown T, ed.). Oxford: Wiley-Blacwell; 2010.

14. Sambrook J, Russel DW. Molecular cloning : a laboratory manual. 1st-3rd ed. New York: Cold Spring Harbor Laboratory Press; 2001.

15. Qiagen. QIAEX ${ }^{\circledR}$ II Handbook for DNA extraction from agarose and polyacrylamide gels and for desalting and concentrating DNA from solutions. Qiagen; 2015.

16. Carrol KC, Butel JS, Morse SA, Mietzner T. Selected medically important microorganisms. 27th ed. United States: McGraw-Hill Education; 2016. 